NOTE

\title{
Seasonal variation of two different heterotrophic bacterial assemblages in subarctic coastal seawater
}

\author{
Mitsuru Yanada*, Taichi Yokokawa, Choon Weng Lee, Hitoshi Tanaka, \\ Isao Kudo, Yoshiaki Maita
}

Division of Marine Environment and Resources, Graduate School of Fisheries Science, Hokkaido University, Hakodate 041-8611, Japan

\begin{abstract}
The numbers of heterotrophic bacteria in the subarctic coastal seawater of Funka Bay, Japan, were measured by flow cytometry, and 2 different bacterial assemblages were detected: cells with low DNA content (Group I) and cells with high DNA content (Group II). Although the abundances of both Group I and Group II bacteria showed similar regression slopes against seawater temperature $(p>$ $0.7)$, Group II bacteria consisted of high growth capacity cells, growing actively in an enriched incubation experiment, whereas Group I bacteria consisted of inactive cells, not responding to an enriched environment. The seasonal variation of the total bacterial abundance observed in Funka Bay was caused almost exclusively by Group II bacteria.
\end{abstract}

KEY WORDS: Heterotrophic bacteria - Flow cytometry • Seasonal variation $\cdot$ Subarctic coastal seawater

Resale or republication not permitted without written consent of the publisher

The function of bacteria is significantly implicated in the energy flow of the carbon cycle or the trophic dynamics in seawater (Kirchman et al. 1993). Bacterial abundances in seawater have been traditionally dealt with as a homogenous bacterial assemblage using epifluorescence microscopy (Porter \& Feig 1980, Cho \& Azam 1990, Kirchman et al. 1993). However, in recent years bacterial abundances in marine environments have been measured using a flow cytometer, which can obtain more information about particle size and fluorescence intensity of selected fluorochromes ( $\mathrm{Li}$ et al. 1995, Marie et al. 1996, Zubkov et al. 1998). The objective of this paper is to describe the seasonal variation of the 2 bacterial groups obtained by flow cytometry using samples stained with the fluorochrome Picogreen ${ }^{\circledR}$, and to suggest that the seasonal variation of total bacterial abundance was caused almost exclusively by actively growing cells with high DNA content.

*E-mail: yanada@mespc4.fish.hokudai.ac.jp
Seawater samples were collected at $10 \mathrm{~m}$ intervals from Stn FB30 (42 $16.2^{\prime} \mathrm{N}, 143^{\circ} 36.0^{\prime} \mathrm{E}$, depth is $\left.92 \mathrm{~m}\right)$, located in Funka Bay, Japan, from August 1998 to July 1999. The hydrographical environment in Funka Bay is typical of subarctic coastal seawater, with pycnocline from May to November and vertical mixing from December to March. However, the intrusion of a different water mass with low salinity was found in the water column above $40 \mathrm{~m}$ depth in April.

Seawater samples were immediately preserved with $1 \%$ (final conc.) of paraformaldehyde solution. The preserved samples were frozen immediately in liquid nitrogen and stored at $-80^{\circ} \mathrm{C}$. Analysis was carried out within $2 \mathrm{wk}$ after sampling. Subsamples (2 to $3 \mathrm{ml}$ ) were stained with the fluorochrome Picogreen ${ }^{\circledR}$. The green fluorescence (indicative of DNA content), the side scatter (indicative of size) and red fluorescence (indicative of chlorophyll a content) in stained samples were measured with a flow cytometer (EPICS ELITE; Beckman Coulter Inc., Fullerton, CA, USA. Data analysis was performed with Win MDI 2.8 (Joseph Trotter) software. According to Li et al. (1995) and Zubkov et al. (1998), the numbers of heterotrophic bacteria were obtained by counting particles with green fluorescence and not those with red fluorescence (cyanobacteria and pico-phytoplankton). The size of the green fluorescence particles observed was less than $1 \mu \mathrm{m}$ (relative to $1 \mu \mathrm{m}$ standard beads), and Prochlorococcus was not detected in all the samples measured. Concurrent epifluorescence microscopy using the DAPI method (Porter \& Feig 1980) was also carried out.

Counts from the flow cytometry were highly correlated with those estimated by epifluorescence microscopy of DAPI-stained cells $\left(\mathrm{r}^{2}=0.64, \mathrm{p}<0.01, \mathrm{n}=53\right)$. Linear regression analysis yielded a slope $( \pm 95 \%$ confindence limit) of $0.76 \pm 0.08$ and a $y$ intercept $( \pm 95 \%$ confidence limit) of $0.8 \pm 0.5 \times 10^{5}$ cells ml ${ }^{-1}$ (Fig. 1). The flow cytometry method essentially detected the 


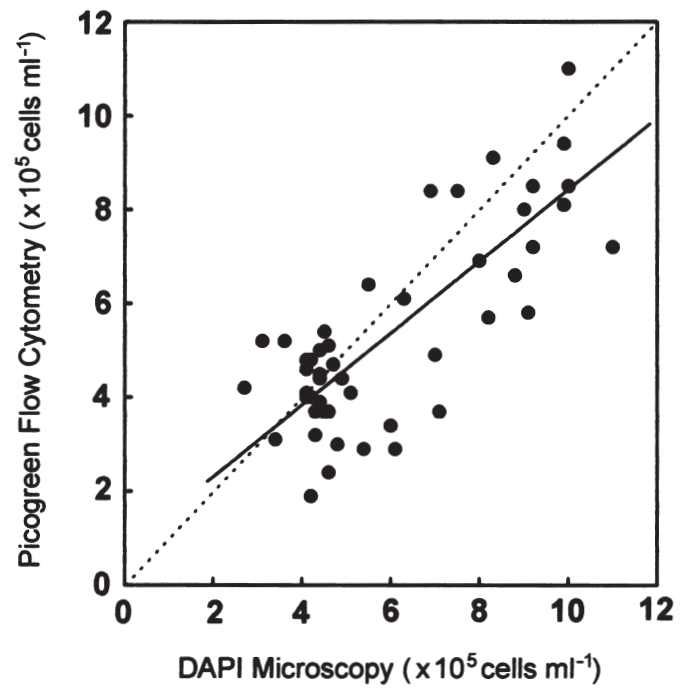

Fig. 1. Relationship between the abundances of heterotrophic bacteria obtained by DAPI epifluorescence microscopic observation and the abundances of heterotrophic bacteria obtained by Picogreen ${ }^{\circledR}$ flow cytometric observation $(y=$ $\left.0.76 x+7.8 \times 10^{4}, r^{2}=0.64, p<0.01, n=53\right)$. The broken line shows a 1:1 relationship

same bacterial population measured with the DAPI method. Mean coefficient of variation $(\mathrm{CV})$ for the flow cytometry method was $2.5 \%$, whereas for the DAPI method the mean $\mathrm{CV}$ was $8.6 \%$.

In this study, flow cytometry analysis detected 2 different heterotrophic bacterial assemblages of the same size, as in Li et al. (1995): cells with relatively weak green fluorescence, suggesting low apparent DNA content (Group I), and cells with relatively intense green fluorescence, suggesting high apparent DNA content (Group II) (Fig. 2).

From August to November, the total bacterial abundance (Group I + Group II) was relatively high in the upper $40 \mathrm{~m}$ when compared to that below $40 \mathrm{~m}$ depth (Fig. 3). In February total bacterial abundances were low and vertically uniform, whereas in March the total bacterial abundance increased 2-fold. Although total bacterial abundance decreased in the upper $40 \mathrm{~m}$ in April, probably due to the exchange of water masses, it remained high below $50 \mathrm{~m}$ depth. In May, the total bacterial abundances increased dramatically throughout the water column, and remained relatively high until July.

From August to February, the abundances of both Group I and Group II bacteria were similar throughout the water column. However from March to May, the increase in total bacterial abundance was reflected only by an increase in Group II bacteria. The contribution of Group II bacteria to the total bacterial abundance increased from $46 \%$ in February to $85 \%$ in May, and remained above $60 \%$ throughout the summer. In contrast, the abundance of Group I bacteria was low, and remained relatively constant throughout the sampling period. Therefore the seasonal variation of the total bacterial abundance was caused almost exclusively by Group II bacteria.

An incubation experiment was carried out to determine the growth rates of both Group I and Group II bacteria (Fig. 4). Seawater samples were diluted 10 -fold in $0.2 \mu \mathrm{m}$ filtered seawater enriched with glucose (10 $\mu \mathrm{M}$ added). The incubation was carried out at $16^{\circ} \mathrm{C}$, and subsamples were taken every hour. Total bacterial abundance increased with incubation time, and the total bacterial growth rate measured was $0.8 \mathrm{~d}^{-1}$. However only Group II bacteria increased with incubation time, at a growth rate of $1.2 \mathrm{~d}^{-1}$, whereas no significant increase in abundance was detected for Group I bacteria $(\mathrm{p}>0.05)$.

From the seasonal variation of both Group I and Group II bacteria, we found that Group I bacteria were significantly correlated with in situ seawater temperature $(\mathrm{p}<0.01)$ (Fig. 5). For Group II bacteria, only the data from August to February showed a significant positive correlation with temperature $(p<0.01)$. From March until July, when the spring bloom and bloom decay period occurred, the abundance of Group II bacteria was high, even at low seawater temperatures ( 2 to $16^{\circ} \mathrm{C}$ ). When the regression equations from both Group I and Group II bacteria (data from August to February) were compared, there was no significant difference (Student's $t$-test, $\mathrm{p}>0.7$ ).

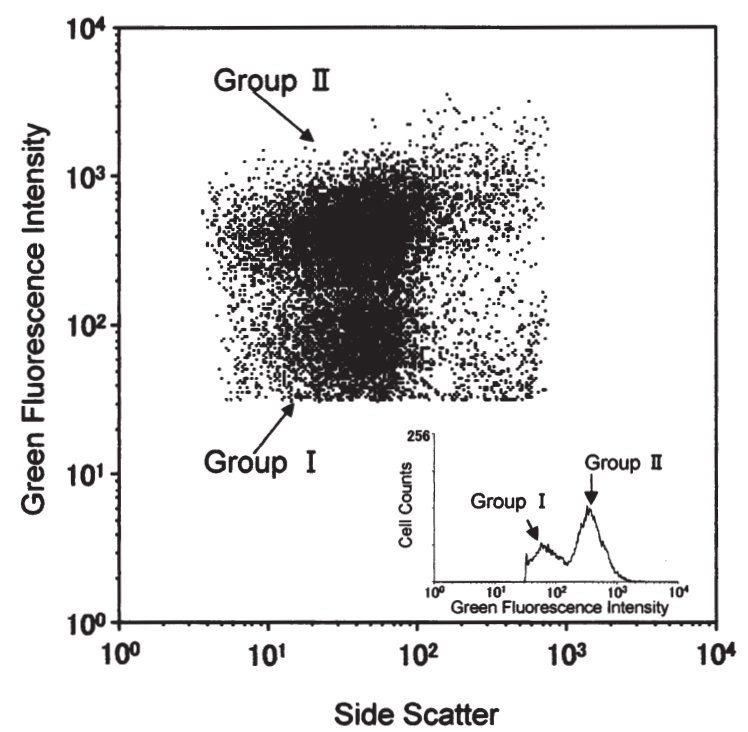

Fig. 2. Flow cytometric analysis of green fluorescence versus side scatter showing heterotrophic bacteria (sample was from $90 \mathrm{~m}$ depth in April 1999). Dots indicate cells. At the bottom right of the graph, the histogram shows the cell number at different green fluorescence intensities 
Bacterial Abundance $\left(\times 10^{5}\right.$ cells $\left.\mathrm{ml}^{-1}\right)$
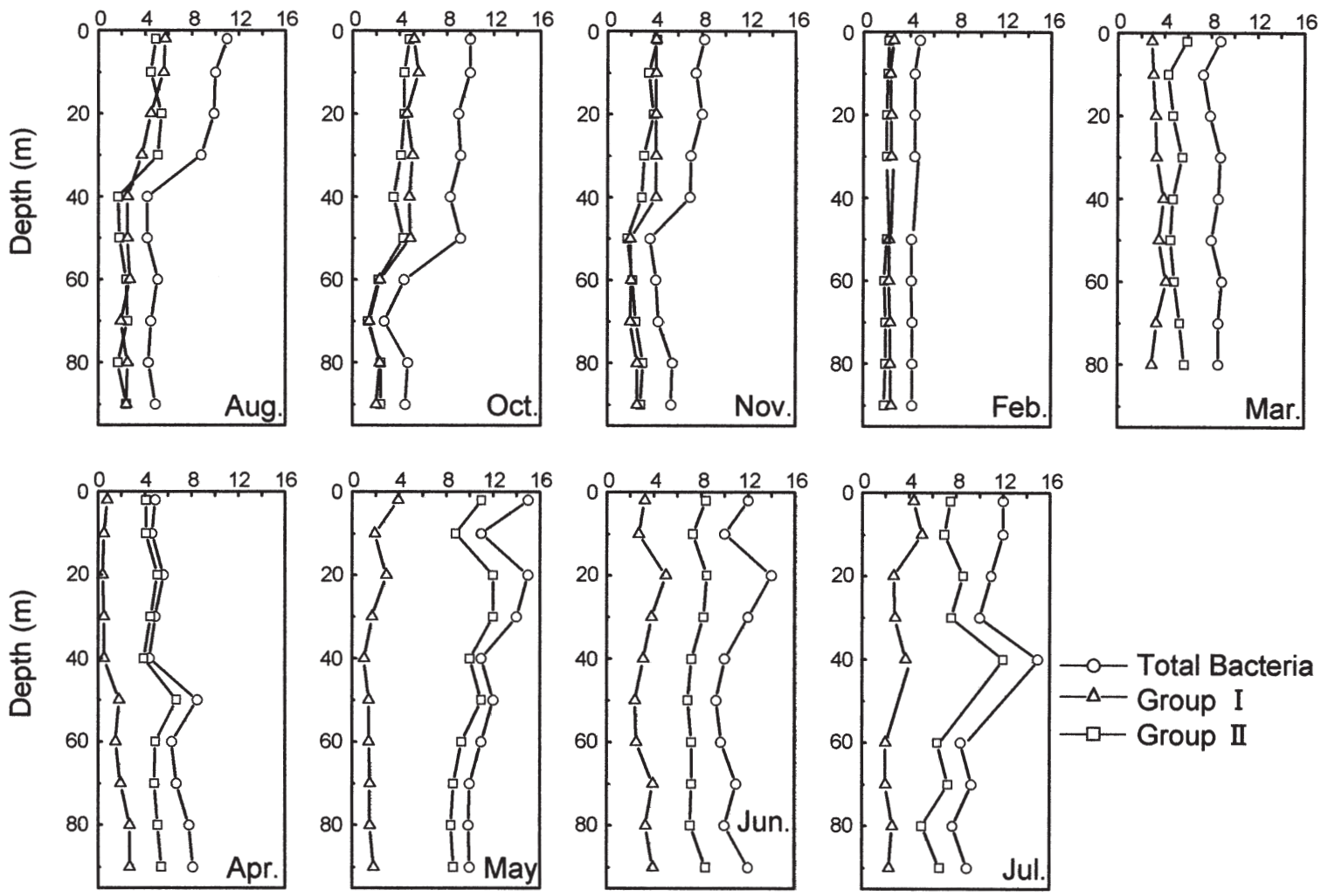

Fig. 3. Vertical profiles of bacterial abundances in both Group I and Group II, and total bacterial abundances (Group I + Group II) in Funka Bay, Japan, from August 1998 to July 1999

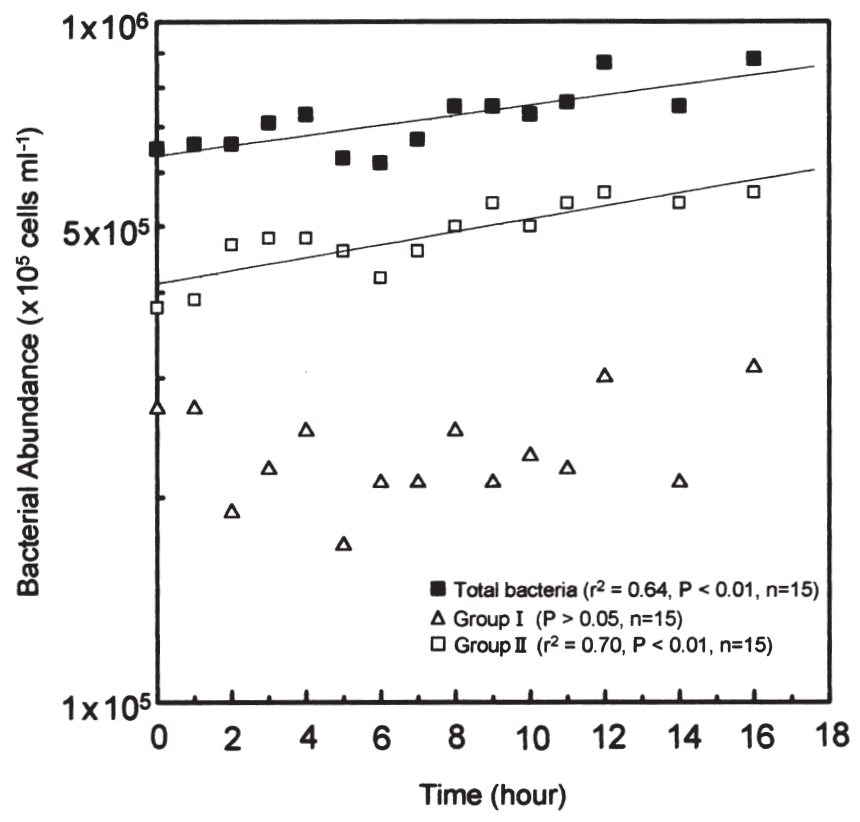

Fig. 4. Time-course incubation experiment on the growth rates of heterotrophic bacterial assemblages (sample was from $10 \mathrm{~m}$ depth in July 1999) diluted 1:10 and enriched with glucose

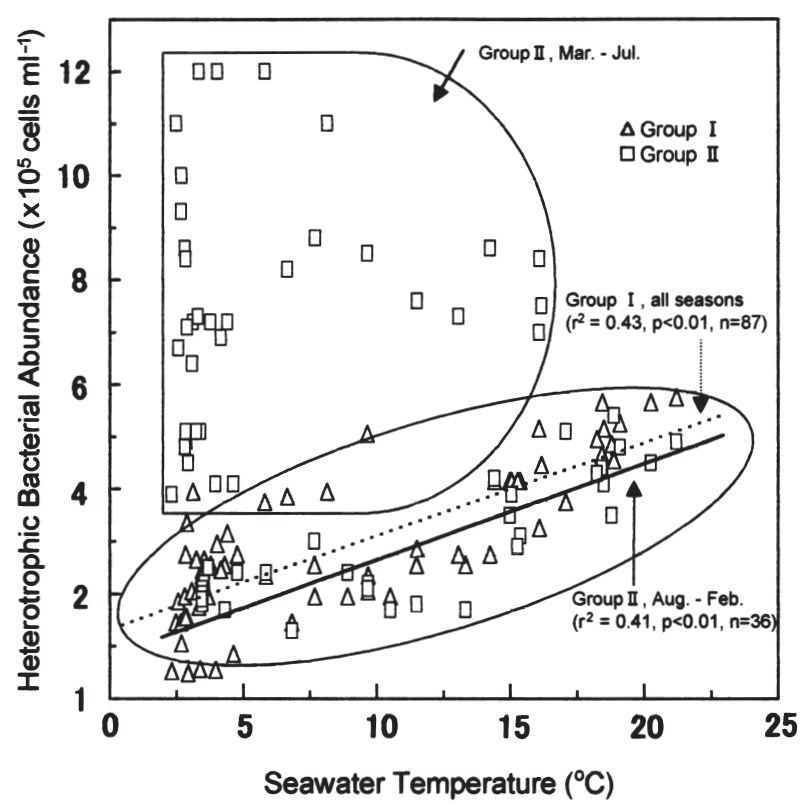

Fig. 5. Relationship between heterotrophic bacterial abundances and seawater temperature observed throughout the study 
These results showed that the abundances of both Group I and Group II bacteria were similarly affected by an increase in seawater temperature. However, Group II bacteria comprised cells with high growth capacity and which grew actively, whereas Group I bacteria consisted of inactive cells that did not respond to an enriched environment.

In conclusion, the heterotrophic bacteria in seawater could be presented as 2 different groups: low apparent DNA content (Group I) and high apparent DNA content (Group II). The seasonal variation of the total bacterial abundance observed in Funka Bay was caused almost exclusively by Group II bacteria.

Acknowledgements. We are grateful to the captain and crew of the RV 'Ushio Maru', Graduate School of Fisheries Science, Hokkaido University, for their assistance during sampling.

Editorial responsibility: Gerhard Rheinheimer (Contributing Editor), Kiel, Germany

\section{LITERATURE CITED}

Cho BC, Azam F (1990) Biogeochemical significance of bacteria biomass in the ocean's euphotic zone. Mar Ecol Prog Ser 63:253-259

Kirchman DL, Kiel RG, Simon M, Welschmeyer NA (1993) Biomass and production of heterotrophic bacterioplankton in the oceanic subarctic Pacific. Deep-Sea Res 40:967-988

Li WKW, Jellett JF, Dickie PM (1995) DNA distribution in planktonic bacteria stained with TOTO or TO-PRO. Limnol Oceanogr 40:1485-1495

Marie D, Vaulot D, Partensky F (1996) Application of the novel nucleic acid dyes YOYO-1, YO-PRO-1, and Picogreen for flow cytometeric analysis of marine prokaryotes. Appl Environ Microbiol 62:1649-1655

Porter KG, Feig YS (1980) The use of DAPI for identifying and counting aquatic microflora. Limnol Oceanogr 25:943-948

Zubkov MV, Sleigh MA, Tarran GA, Burkill PH, Leakey RJG (1998) Picoplanktonic community structure on an Atlantic transect from $50^{\circ} \mathrm{N}$ to $50^{\circ} \mathrm{S}$. Deep-Sea Res 45:1339-1355

Submitted: February 2, 2000; Accepted: July 18, 2000

Proofs received from author(s): September 12, 2000 